\title{
TOMATO YELLOW VEIN STREAK VIRUS: RELATIONSHIP WITH BEMISIA TABACI BIOTYPE B AND HOST RANGE
}

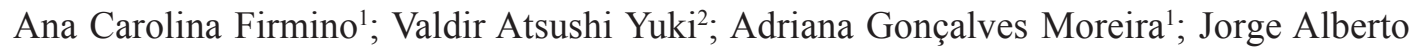 \\ Marques Rezende ${ }^{3 *}$ \\ ${ }^{l}$ USP/ESALQ - Programa de Pós-Graduação em Fitopatologia. \\ ${ }^{2}$ APTA/IAC - C.P. 28 - 13001-970 - Campinas, SP - Brasil. \\ ${ }^{3}$ USP/ESALQ - Depto. de Fitopatologia e Nematologia - C.P. 09 - 13418-900 - Piracicaba, SP - Brasil. \\ *Corresponding author<jamrezen@esalq.usp.br>
}

\begin{abstract}
The Tomato yellow vein streak virus (ToYVSV) is a putative species of begomovirus, which was prevalent on tomato crops in São Paulo State, Brazil, until 2005. The objectives of this study were to evaluate the interaction between ToYVSV and its vector Bemisia tabaci biotype B and to identify alternative hosts for the virus. The minimum acquisition and inoculation access periods of ToYVSV by B. tabaci were $30 \mathrm{~min}$ and $10 \mathrm{~min}$, respectively. Seventy five percent of tomato-test plants were infected when the acquisition and inoculation access periods were $24 \mathrm{~h}$. The latent period of the virus in the insect was $16 \mathrm{~h}$. The ToYVSV was retained by $B$. tabaci until 20 days after acquisition. First generation of adult whiteflies obtained from viruliferous females were virus free as shown by PCR analysis and did not transmit the virus to tomato plants. Out of 34 species of test-plants inoculated with ToYVSV only Capsicum annuum, Chenopodium amaranticolor, C. quinoa, Datura stramonium, Gomphrena globosa, Nicotiana clevelandii and N. tabacum cv. TNN were susceptible to infection. B. tabaci biotype B was able to acquire the virus from all these susceptible species, transmitting it to tomato plants.
\end{abstract}

Key words: Solanum lycopersicon, geminivirus, begomovirus, aleyrodidae, transmission

\section{TOMATOYELLOW VEIN STREAK VIRUS: INTERAÇÃOCOMA BEMISIA TABACI BIÓTIPO B E GAMA DE HOSPEDEIROS}

\begin{abstract}
RESUMO: O Tomato yellow vein streak virus (ToYVSV) é uma espécie putativa de begomovirus que infecta o tomateiro (Solanum lycopersicon) em diversas regiões do Brasil onde se cultiva essa solanácea, sendo a espécie prevalente no estado de São Paulo até 2005. Estudou-se a interação do ToYVSV com a Bemisia tabaci biótipo B e identificaram-se hospedeiras alternativas deste vírus. Os períodos de acesso mínimo de aquisição (PAA) e de inoculação (PAI) foram de $30 \mathrm{~min}$ e $10 \mathrm{~min}$, respectivamente. A porcentagem de plantas infectadas chegou até cerca de $75 \%$ após um PAA e PAI de $24 \mathrm{~h}$. O período de latência do vírus no vetor foi de 16 horas. O ToYVSV foi retido pela $B$. tabaci até 20 dias após a aquisição do vírus. Não foi detectada transmissão do vírus para progênie da $B$. tabaci biótipo B oriundas de insetos virulíferos. De 34 espécies de plantas testadas como hospedeiras somente Capsicum annuum, Chenopodium amaranticolor, C. quinoa, Datura stramonium, Gomphrena globosa, Nicotiana clevelandii e N. tabacum cv. TNN foram suscetíveis à infecção com o ToYVSV, por meio de inoculação com a B. tabaci. As espécies susceptíveis ao ToYVSV serviram de fonte de inóculo para a transmissão do vírus para tomateiros por meio de $B$. tabaci biótipo B.

Palavras-chave: Solanum lycopersicon, geminivirus, begomovirus, aleyrodidae, transmissão
\end{abstract}

\section{INTRODUCTION}

Recent studies on molecular characterization of begomoviruses infecting tomato plants (Solanum lycopersicon) indicated the existence of a complex diversity of species in Brazil (Ambrozevícius et al., 2002; Ribeiro et al., 2003), resulting from the introduction and dispersal throughout the country of the effective vec- tor Bemisia tabaci biotype B since the 1990's (Lourenção \& Nagai, 1994; França et al., 1996). Currently, this complex comprises four recognized species, at least eight other potential species, including Tomato yellow vein streak virus (ToYVSV) (Colariccio et al., 2007), and some recombinant forms of this virus, which have not been properly characterized (Ambrozevícius et al., 2002; Calegario et al., 2007; Fernandes et al., 2008). 
The first report on ToYVSV infecting tomato plants in Brazil occurred in 1997, in the region of Campinas, State of São Paulo (Faria et al., 1997). In this region, incidence of ToYVSV infected plants ranging from $58 \%$ to $100 \%$ in 2003 and from 14 to $27 \%$ in 2004 were observed (Rezende, J.A.M. data not published). In tomato plants cultivated under plastic greenhouse conditions the incidence of ToYVSV ranged from $4.8 \%$ to $69.3 \%$, depending on the planting season (Vecchia et al., 2007). This virus has also been previously reported to infect green pepper (Capsicum annuum) (Nozaki, 2006) and potato (Solanum tuberosum) (Ribeiro et al., 2006; Souza-Dias et al., 1996).

The acquisition and transmission of begomoviruses by $B$. tabaci has been extensively studied, and these parameters can vary depending on the virus and the aleyrodid biotype (Cohen \& Nitzany, 1966; Polston et al., 1990; Zeidan \& Czosnek, 1991; Mehta et al., 1994a; Rubinstein \& Czosnek, 1997; Ghanim \& Czosnek, 2000; Muniyappa et al., 2000). Determining these parameters, together with knowledge on the range of virus hosts, allows to elucidate the epidemiology of different begomovirus diseases, as well as to develop disease management strategies. In Brazil, up to now these parameters have been identified only for the transmission of one begomovirus isolate, taxonomically related to Tomato rugose mosaic virus (ToRMV), by B. tabaci biotype B (Santos et al., 2003).

This study aimed to investigate the acquisition, retention and transmission of a ToYVSV isolate by $B$. tabaci biotype $\mathrm{B}$, and to identify potential alternative virus hosts.

\section{MATERIALAND METHODS}

\section{ToYVSV isolate and B. tabaci biotype B mainte- nance}

The ToYVSV isolate used in this study was maintained in tomato plants by B. tabaci transmission. The identity of the virus was confirmed by partial DNA-A nucleotide sequence analysis of a fragment flanking the common region (RC) and the 5' of the coat protein gene ( $c p$ ) (data not shown). Virus-free B. tabaci biotype B adults were reared on collard greens (Brassica oleraceae), soybean (Glycine max), and tomato plants, maintained in a greenhouse equipped with insect-proof screen. The B. tabaci species/biotype was identified by Dr. Geni L. Villas Boas and Dr. Maria Esther N. F. Boiteux (Embrapa Hortaliças). In addition, the whiteflies induced silvery leaf on Cucurbita pepo cv. Caserta, which is characteristic of this biotype.

ToYVSV detection by PCR

DNA extraction from tomato leaves and from $B$. tabaci biotype B nymphs and adults was achieved according to the methods described by Dellaporta et al. (1983) and Mehta et al. (1994b), respectively. Total DNA was used in a PCR reaction using the degenerate primer pairs PAR1c715/PAL1v1978, which amplifies a DNA A fragment with approximately 1,300 bp, and PBL1v2040/ PCRc1, which amplifies a DNA B fragment with approximately 500 to 650 bp (Rojas et al., 1993).

Determination of ToYVSV acquisition (AAP) and inoculation access period (IAP) by $B$. tabaci biotype B

Adult, virus-free B. tabaci individuals were placed in $50 \mathrm{~mL}$ polypropylene vials ( $\mathrm{ca} 150$ insects) containing a ToYVSV-infected tomato leaf, in order to acquire the virus. Nine virus AAP by the vector were evaluated: 10,20 , and $30 \mathrm{~min}, 1,2,4,8,16$, and $24 \mathrm{~h}$. After each AAP, the insects were transferred, in groups of 15 individuals, into pots containing two tomato test plants cultivar Santa Cruz Kada Gigante, at the stage when two true leaves were present. Pots were covered with insect-proof cages, and the insects remained there for a $24 \mathrm{~h}$ feeding period. To evaluate the IAP, the virus-free insects were initially submitted to a 24 $\mathrm{h}$ virus AAP. Groups of 15 insects were transferred to tomato test plants as described above. Nine virus IAP by the vector were evaluated: 10,20 , and $30 \mathrm{~min}$, $1,2,4,8,16$, and $24 \mathrm{~h}$. Ten test plants were used for each AAP and IAP assays. Upon completion of the various AAP and IAP assays, the insects were immediately eliminated by spraying the plants with pyrethroid insecticides and imidacloprid (systemic). The plants were maintained in the greenhouse for periodic symptom evaluations. Infection in all plants was confirmed by PCR for DNA-A detection.

Virus latency period (LP) determination in the vector

The ToYVSV acquisition and transmission processes by $B$. tabaci biotype B were identical to those described previously. After a virus AAP of $1 \mathrm{~h}$ the insects were transferred to healthy tomato test plants. Fifteen insects were used per each two plants. Virus IAPs of $7,9,11,13,15$, and $23 \mathrm{~h}$ were adopted. After each period, the insects were immediately eliminated as previously described. Ten test plants were used for each IAP. Periodical symptom evaluations were conducted, and plant infection was confirmed by DNA-A detection by PCR.

\section{Determination of virus retention period by the vector}

Approximately 1000 B. tabaci biotype B adults had a ToYVSV AAP of $48 \mathrm{~h}$ as previously described. The insects were then transferred to a ToYVSV-resistant 
collard greens plant (Brassica oleraceae), maintained in an insect-proof cage inside a greenhouse. Fifteen days later, the insects were transferred to a new collard greens plant to prevent that first-generation adults would perhaps become mixed with previously-transferred virus-bearing insects. Periodically, groups of ten adults were transferred to two tomato test plants for a 48-h virus IAP, while another group of five insects was used for viral DNA-A detection by PCR. This procedure was repeated eight times over a period from 15 to 20 days, until no more insects were found.

ToYVSV detection in the $B$. tabaci progeny

B. tabaci biotype B adults had a ToYVSV AAP of $24 \mathrm{~h}$ as previously described. Approximately 50 insects were immediately transferred into four tomato test plants, for a 24-h IAP in order to later confirm insect infectivity. Another 50 insects were transferred to a ToYVSVresistant eggplant individual (Solanum melongena), placed in an insect-proof cage inside a greenhouse. The insects remained in the eggplants for 12 days to oviposit and were then eliminated manually. Fifty fourthinstars nymphs were collected from the eggplant leaves for viral DNA-A detection by PCR. The nymphs were analyzed in groups of 10 . Adults emerged from the eggplant were transferred to tomato test plants for a virus IAP of $24 \mathrm{~h}$. Twenty to 30 insects were confined in four test plants. Some of those adults were later collected for viral DNA-A detection by PCR.

\section{Identification of ToYVSV host plants}

The plant species inoculated with the ToYVSV isolate by means of virus-bearing $B$. tabaci biotype $\mathrm{B}$ adults are listed in table 5. In two assays the insects had 24-h virus AAPs and were then transferred to test plants of various species for a 48 -h virus IAP, and were then eliminated as previously described. Twenty insects were confined into groups of three test plants of each species. In the third assay, the test plants of the various species were confined in an insect-proof cage containing a virus-bearing colony of the aleyrodid. The test plants remained exposed to the virus-bearing insects for $48 \mathrm{~h}$, and were then removed and sprayed with systemic insecticide (imidacloprid). All test plants inoculated were maintained in the greenhouse and were evaluated periodically for the expression of symptoms. Leaf samples of symptomatic and asymptomatic plants were collected 30 and 90 days after inoculation for DNA-A and DNA-B detection by PCR.

\section{RESULTS AND DISCUSSION}

\section{Interaction between ToYVSV and $B$. tabaci biotype B}

The the minimum access periods for ToYVSV acquisition and inoculation by $B$. tabaci biotype B were 30 and 10 minutes, respectively. Infected plant means of 20 and $35 \%$ were obtained, respectively. A gradual increase occurred in number of infected plants as virus AAP and IAP increased, reaching $70 \%$ and $75 \%$ at an AAP and IAP of $24 \mathrm{~h}$, respectively (Table 1). The PCR analysis for DNA-A detection confirmed that the plants were infected (data not shown).

The minimum ToYVSV acquisition and inoculation periods by $B$. tabaci are slightly different from those found for the transmission of a begomovirus isolate taxonomically related to ToRMV by the same insect in Brazil (Santos et al., 2003), which were of 15 and 30 min, respectively. Results similar to the ones observed in the present study were obtained in the transmission of Cotton leaf curl virus form India (CLCuKV), Squash leaf curl virus (SLCV), Tomato leaf curl Bangalore virus - C (ToLCBV-C) (sin. Tomato leaf curl virus from Bangalore, India - ToLCVBan4), and Tomato yellow leaf curl virus (TYLCV-EG) isolate from Egypt by B. tabaci biotype B (Cohen et al., 1983; Nateshan et al., 1996; Muniyappa et al., 2000; Mehta et al., 1994a). A TYLCV isolate from Jordan had minimum acquisition and inoculation access periods of 60 and 30 minutes, respectively (Mansour \& Al-Musa, 1992). Longer acquisition and inoculation access periods, of $1 \mathrm{~h}$ and $2 \mathrm{~h}$, respectively, were observed in an interaction between Chino del tomate virus (CdTV) and B. tabaci biotype B (Brown \& Nelson, 1988).

Table 1 - Transmission of Tomato yellow vein streak virus (ToYVSV) by Bemisia tabaci biotype B after different acquisition access (AAP) and inoculation access periods (IAP).

\begin{tabular}{|c|c|c|c|c|c|c|c|c|c|c|c|}
\hline \multicolumn{3}{|l|}{ Time } & $10 \mathrm{~min}$ & $20 \min$ & $30 \mathrm{~min}$ & $1 \mathrm{~h}$ & $2 \mathrm{~h}$ & $4 \mathrm{~h}$ & $8 \mathrm{~h}$ & $16 \mathrm{~h}$ & $24 \mathrm{~h}$ \\
\hline \multirow[t]{3}{*}{ AAP* } & No. of infected/ & Exp. 1 & $0 / 10$ & $0 / 10$ & $2 / 10$ & $2 / 10$ & $2 / 10$ & $4 / 10$ & $2 / 10$ & $8 / 10$ & $8 / 10$ \\
\hline & Inoculated plants & Exp. 2 & $0 / 10$ & $0 / 10$ & $2 / 10$ & $3 / 10$ & $5 / 10$ & $3 / 10$ & $3 / 10$ & $5 / 10$ & $6 / 10$ \\
\hline & Means of infecte & lants $(\%)$ & 0 & 0 & 20 & 25 & 35 & 35 & 25 & 65 & 70 \\
\hline \multirow[t]{3}{*}{$\mathrm{IAP} * *$} & No. of infected/ & Exp. 1 & $4 / 10$ & $5 / 10$ & $4 / 10$ & $4 / 8$ & $4 / 8$ & $4 / 10$ & $4 / 10$ & $6 / 10$ & $8 / 10$ \\
\hline & Inoculated plants & Exp. 2 & $3 / 10$ & $4 / 10$ & $4 / 10$ & $5 / 10$ & $5 / 10$ & $4 / 10$ & $4 / 10$ & $8 / 10$ & $7 / 10$ \\
\hline & Means of infecte & lants $(\%)$ & 35 & 45 & 40 & 50 & 50 & 40 & 40 & 70 & 75 \\
\hline
\end{tabular}

$* 24 \mathrm{~h}$ access to ToYVSV inoculation; **24 $\mathrm{h}$ access to ToYVSV acquisition 
The ToYVSV latency period (LP) in B. tabaci biotype $B$ adults was $16 \mathrm{~h}$ as determined in two independent experiments (Table 2). This result was identical to the LP reported for a ToRMV isolate from Brasília, Brazil (Santos et al., 2003) and similar to the LP for CdTV, which was approximately 17 h (Brown \& Nelson, 1988). The SLCV LP in B. tabaci biotype B was $19 \mathrm{~h}$, while the LP for the TYLCV isolate from Jordan was 20 - 24 h (Cohen et al., 1983; Mansour \& Al-Musa, 1992), a little higher than the value obtained for ToYVSV. A LP longer than $24 \mathrm{~h}$ was found for the TYLCV isolate from Egypt (Mehta et al., 1994a), while a 6-h LP was reported for ToLCBV-C (Muniyappa et al., 2000).

B. tabaci biotype B adults that had a ToYVSV AAP of $48 \mathrm{~h}$ and were then maintained in a plant immune to the virus were capable of transmitting the virus for up to 20 days after acquisition. The virus presence in the insects was confirmed by PCR (Table 3 ). In both experiments, the number of infected plants decreased gradually, although the virus was detected in the insects until 25 days after acquisition. This reduction in

Table 2 - Transmission of Tomato yellow vein streak virus (ToYVSV) by Bemisia tabaci biotype B after a virus acquisition access period (AAP) of 1 hour and different inoculation access periods (IAP).

\begin{tabular}{|c|c|c|c|}
\hline \multirow{2}{*}{ IAP (h) } & \multirow{2}{*}{$\begin{array}{l}\text { Latency period } \\
\text { (h)* }\end{array}$} & \multicolumn{2}{|c|}{$\begin{array}{l}\text { Number of infected/ } \\
\text { inoculated plants }\end{array}$} \\
\hline & & Experiment 1 & Experiment 2 \\
\hline 7 & 8 & $0 / 12$ & $0 / 12$ \\
\hline 9 & 10 & $0 / 12$ & $0 / 12$ \\
\hline 11 & 12 & $0 / 12$ & $0 / 12$ \\
\hline 13 & 14 & $0 / 12$ & $0 / 12$ \\
\hline 15 & 16 & $1 / 12$ & $1 / 12$ \\
\hline 23 & 24 & $2 / 12$ & $1 / 12$ \\
\hline
\end{tabular}

$*$ Latency period $=\mathrm{IAP}+\mathrm{AAP}$ of $1 \mathrm{~h}$. the number of infected plants might have occurred because ToYVSV concentration decreased in $B$. tabaci biotype $\mathrm{B}$, since the relationship of begomoviruses with this insect is of a persistent-circulative nature, without virus replication in the insects. A TYLCSV quantitative study in virus-bearing $B$. tabaci biotype B adults indicated a reduction of $9 \%$ per day in virus genome detection in insects maintained in a virus-immune host (Mason et al., 2008).

The retention period of different begomoviruses in B. tabaci biotype B adults is also quite variable, from four to seven days in the case of CdTV (Brown \& Nelson, 1988), nine days for Tomato leaf curl Sinaloa virus (ToLCSinV) (sin. Sinaloa tomato leaf curl virus - STLCV) (Idris \& Brown, 1998), 11 to 12 days for ToLCBV-C (Muniyappa et al. 2000), 11 to 20 days for TYLCV isolate from Jordan (Cohen \& Nitzany, 1966; Mansour \& Al-Musa, 1992), and 26 days for SLCV (Cohen et al., 1983). These differences in virus AAP, IAP, LP, and period of retention within the insect are expected because, besides the variations in the conditions of the various experiments, especially with respect to insect numbers and the manner by which those insects were handled, other variables, such as begomovirus species, geographic origin of the virus isolate and of the $B$. tabaci biotype B population might affect these parameters, as reported in studies involving other begomoviruses (Picó et al., 1996; Muniyappa et al., 2000).

The ToYVSV did not pass onto the $B$. tabaci biotype B progeny, whose adults initially acquired the virus from infected tomato plants. Aleyrodid adult samples from each of the five independent experiments conducted were able to transmit ToYVSV right after acquisition, and thus proved to be viruliferous. Nevertheless, PCR analyses of total DNA extracted from first-generation nymphs and adults did not detect ToYVSV DNA-A. No tomato test plant became

Table 3 - Detection of Tomato yellow vein streak virus (ToYVSV) in Bemisia tabaci biotype B adults by PCR and number of plants infected by transmission with insects until 25 days after virus acquisition.

\begin{tabular}{|c|c|c|c|c|}
\hline \multirow{2}{*}{ Days after virus acquisition } & \multicolumn{2}{|c|}{ Positive PCR Samples/No. samples tested* } & \multicolumn{2}{|c|}{ No. of infected plants/No. of inoculated plants** } \\
\hline & Exp. 1 & Exp. 2 & Exp. 1 & Exp. 2 \\
\hline 0 & $3 / 4$ & $3 / 4$ & $4 / 4$ & $4 / 4$ \\
\hline 3 & $3 / 4$ & $4 / 4$ & $3 / 4$ & $3 / 4$ \\
\hline 6 & $2 / 4$ & $4 / 4$ & $2 / 2$ & $2 / 3$ \\
\hline 9 & $4 / 4$ & $4 / 4$ & $2 / 4$ & $2 / 2$ \\
\hline 12 & $4 / 4$ & $4 / 4$ & $1 / 3$ & $1 / 4$ \\
\hline 15 & $4 / 4$ & $4 / 4$ & $1 / 3$ & $1 / 4$ \\
\hline 20 & $3 / 4$ & $3 / 4$ & $1 / 4$ & $0 / 4$ \\
\hline 25 & $4 / 4$ & NT & $0 / 4$ & NT \\
\hline
\end{tabular}

*Each sample consisted of five B. tabaci adults; ** Infection confirmed by PCR; NT: Not tested due to insect death. 
infected when inoculated with first-generation adults (data not shown). Evidence for the lack of transmission of other begomoviruses into virus-bearing $B$. tabaci biotype $\mathrm{B}$ progenies has been reported previously (Costa, 1976; Idris \& Brown, 1998). On the other hand, the nucleic acid from the Brasília ToRMV isolate was detected by PCR in all nymph stages and adults of $B$. tabaci biotype B from a virus-bearing colony, although adults were not capable of transmitting the virus to tomato plants (Santos et al., 2003). For TYLCV, however, Ghanim et al. (1998) showed that the virus can be transmitted through the eggs of B. tabaci biotype B for at least two generations.

\section{ToYVSV host species}

Among the 34 species tested, only $C$. annuиm, $C$. amaranticolor, C. quinoa, D. stramonium, G. globosa, $N$. clevelandii and $N$. tabacum cv. TNN were identified as susceptible to ToYVSV (Table 4). C. amaranticolor, C. quinoa and G. globosa were asymptomatic, while $C$. annuum, D. stramonium, $N$. clevelandii and $N$. tabacum cv. TNN exhibited mild systemic invasion symptoms.

Table 4 - Reaction of different plant species inoculated with Tomato yellow vein streak virus (ToYVSV) by means of Bemisia tabaci biotype B.

\begin{tabular}{|c|c|c|c|c|}
\hline \multirow{2}{*}{ Species tested } & \multicolumn{4}{|c|}{ No. of positive PCR plants/No. of inoculated plants* } \\
\hline & Exp. 1 & Exp. 2 & Exp. 3 & Symptoms** \\
\hline Abelmoschus esculentus & $0 / 6$ & $0 / 6$ & $0 / 6$ & - \\
\hline Amaranthus viridis & $0 / 6$ & $0 / 6$ & $0 / 6$ & - \\
\hline Capsicum annuum cv. Magali $\mathrm{R}$ & $3 / 6$ & $3 / 6$ & $4 / 6$ & M \\
\hline C. baccatum & $0 / 6$ & $0 / 6$ & NT & - \\
\hline Chenopodium amaranticolor & $2 / 6$ & $1 / 6$ & $2 / 6$ & NS \\
\hline C. quinoa & $1 / 6$ & $1 / 6$ & $1 / 6$ & NS \\
\hline Commelina benghalensis & $0 / 6$ & $0 / 6$ & $0 / 6$ & - \\
\hline Curcubita pepo cv. Caserta & $0 / 6$ & $0 / 6$ & $0 / 6$ & - \\
\hline Datura metel & $0 / 6$ & $0 / 6$ & NT & - \\
\hline D. stramonium & $3 / 6$ & $2 / 6$ & $3 / 6$ & M \\
\hline Euphorbia heterophylla & $0 / 6$ & $0 / 6$ & $0 / 6$ & - \\
\hline Glycine $\max$ cv. Conquista & $0 / 6$ & $0 / 6$ & $0 / 6$ & - \\
\hline Gomphrena globosa & $1 / 6$ & $1 / 6$ & $1 / 6$ & NS \\
\hline Gossypium hirsutum & $0 / 6$ & $0 / 6$ & $0 / 6$ & - \\
\hline Ipomoea grandifolia & $0 / 6$ & $0 / 6$ & $0 / 6$ & - \\
\hline Nicotiana benthamiana & $0 / 6$ & $0 / 6$ & $0 / 6$ & - \\
\hline N. clevelandii & $3 / 6$ & $1 / 6$ & $2 / 6$ & VC, RL \\
\hline N. edwardson & $0 / 6$ & $0 / 6$ & NT & - \\
\hline N. rustica & $0 / 6$ & $0 / 6$ & NT & - \\
\hline N. tabacum cv. Havana & $0 / 6$ & $0 / 6$ & $0 / 6$ & - \\
\hline N. tabacum cv. TNN & $2 / 6$ & $1 / 6$ & $3 / 6$ & VC, RL \\
\hline N. tabacum cv. Turkish & $0 / 6$ & $0 / 6$ & $0 / 6$ & - \\
\hline N. tabacum cv. Xanthi & $0 / 6$ & $0 / 6$ & NT & - \\
\hline Nicandra physaloides & $0 / 6$ & $0 / 6$ & $0 / 6$ & - \\
\hline Oxalis latifolia & $0 / 6$ & $0 / 6$ & $0 / 6$ & - \\
\hline Phaseolus vulgaris & $0 / 6$ & $0 / 6$ & $0 / 6$ & - \\
\hline Physalis floridana & $0 / 6$ & $0 / 6$ & $0 / 6$ & - \\
\hline Raphanus raphanistrum & $0 / 6$ & $0 / 6$ & $0 / 6$ & - \\
\hline Senna obtusifolia & $0 / 6$ & $0 / 6$ & $0 / 6$ & - \\
\hline Sida rhombifolia & $0 / 6$ & $0 / 6$ & $0 / 6$ & - \\
\hline Solanum americanum & $0 / 6$ & $0 / 6$ & $0 / 6$ & - \\
\hline S. sisymbriifolium & $0 / 6$ & $0 / 6$ & $0 / 6$ & - \\
\hline S. tuberosum cv. Cupido & $0 / 6$ & $0 / 6$ & NT & - \\
\hline Sonchus oleraceus & $0 / 6$ & $0 / 6$ & $0 / 6$ & - \\
\hline
\end{tabular}

*Exp. 1 and 2: conducted by confining virus-bearing insects in individual cages; Exp. 3: conducted by exposing the plants to the virusbearing colony. **M: Mosaic; VC: Vein clearing; RL: Rugose leaf; NS: No symptoms; NT: Not tested; -: Lack of infection. 
Symptoms were observed approximately 20 days after inoculation and gradually attenuated as plants grew, becoming imperceptible 90 days after inoculation. Even after that period, extracts from plants identified as susceptible to ToYVSV still gave positive reactions to the presence of DNA A, but not to DNA B (data not presented), which was also not detected in the previous analysis, when plants were younger.

The results for the species susceptible to the ToYVSV isolate used in this study differ partially from those obtained by Souza-Dias et al. (1996), who identified D. stramonium, Physalis sp., N. tabacum cv. Turkish, $P$. vulgaris cv. Preto, Sida micrantha, $S$. rhombifolia and $S$. tuberosum cvs. Bintje, Achat, Monalisa, Spunta, Baraka, Atlantic, and Itararé as susceptible to an isolate of this begomovirus from Sumaré, SP, Brazil, transmitted by B. tabaci biotype B, but not by mechanical inoculation. $N$. benthamiana and $N$. physaloides were other species identified as susceptible to a ToYVSV isolate obtained from potato in the State of Rio Grande do Sul, Brazil, during a transmission test with this aleyrodid (Ribeiro et al., 2006). Although these two isolates were only transmitted by $B$. tabaci biotype B, Colariccio et al. (2007) reported the mechanical transmission of a ToYVSV isolate from Monte Mor, SP, Brazil, from tomato to tomato cv. Carmem. Attempts to accomplish the mechanical transmission of the ToYVSV isolate used in the present study into the seven virus-susceptible species failed (data not presented).

The observation of a restricted range of ToYVSVsusceptible species, with predominance of species in the family Solanaceae, the variation in the expression of symptoms between susceptible species, and their variability with regard to susceptibility to different isolates of the virus are in accordance with reports for other begomovirus species that infect tomato plants, such as ToLCV (Stonor et al., 2003), ToLCSinV (Idris \& Brown, 1998), CdTV (Brown \& Nelson, 1988) and TYLCV (Picó et al., 1996).
Tests conducted to verify whether plants identified as susceptible to ToYVSV can serve as a source of inoculum for virus acquisition by $B$. tabaci biotype B and later transmission to tomato plants gave positive results (Table 5). ToYVSV presence was also confirmed in groups of aleyrodids that fed on the various plant species used as sources of inoculum (data not presented). These results demonstrate the importance of eliminating these plant species from the surroundings of new crops, because they could serve as reservoirs of the virus not only for tomato, but also for potato and green pepper crops, where ToYVSV has been previously found (Souza-Dias et al., 1996; Nozaki, 2006; Ribeiro et al., 2006).

Although monitoring and controlling $B$. tabaci biotype B populations are trivial practices for the control of ToYVSV and other begomoviruses in tomato crops in Brazil, they can be ineffective if virus and vector sources exist in the surroundings. The short period of time (10 $\mathrm{min})$ required for ToYVSV inoculation by $B$. tabaci biotype $\mathrm{B}$ can be sufficient to allow inoculation of the virus into some plants before the insecticide can act upon the insect. Sometimes, the small yield increase obtained with a number of insecticidal sprays for the control of this aleyrodid in order to control the virus disease might not be justified economically and ecologically. Therefore, an integrated management for disease control, which includes the use of available resistant varieties, elimination of tomato plants from old crops as well as weeds that can harbor the virus and the vector before starting the new crop, rational chemical control of vector based on monitoring insect population should be adopted.

\section{ACKNOWLEDGEMENTS}

The authors thank the financial support from FAPESP, proceeding numbers 2006/51601-0 and 2006/ 51608-5.

Table 5 - Transmission of Tomato yellow vein streak virus (ToYVSV) to tomato plants $48 \mathrm{~h}$ after virus acquisition by Bemisia tabaci biotype B in different virus-susceptible species.

\begin{tabular}{|c|c|c|c|}
\hline \multirow{2}{*}{ ToYVSV source plant } & \multicolumn{2}{|c|}{ No. of infected plants/No. of inoculated plants* } & \multirow[t]{2}{*}{ Mean infected plants $(\%)$} \\
\hline & Exp. 1 & Exp. 2 & \\
\hline C. annuum & $1 / 10$ & $6 / 10$ & 30 \\
\hline C. amaranticolor & $0 / 10$ & $4 / 10$ & 20 \\
\hline C. quinoa & $1 / 10$ & $2 / 10$ & 15 \\
\hline D. stramonium & $1 / 10$ & $3 / 10$ & 20 \\
\hline G. globosa & $2 / 10$ & $5 / 10$ & 35 \\
\hline N.clevelandii & $1 / 10$ & $4 / 10$ & 25 \\
\hline N. tabacum cv. TNN & $1 / 10$ & $3 / 10$ & 20 \\
\hline
\end{tabular}

*15 insects per tomato test plant. Inoculation access period $48 \mathrm{~h}$. 


\section{REFERENCES}

AMBROZEVÍCIUS, L.P.; CALEGARIO, R.F.; FONTES, E.P.B.; CARVALHO, M.G.; ZERBINI, F.M. Genetic diversity of begomovirus infecting tomato and associated weeds in Southeastern Brazil. Fitopatologia Brasileira, v.27, p.372$377,2002$.

BROWN, J.K.; NELSON, M.R. Transmission, host range, and virusvector, relationships of Chino del tomato virus, a whiteflytransmitted geminivirus from Sinaloa, Mexico. Plant Disease, v.72, p.866-869, 1988.

CALEGARIO, R.F.; FERREIRA, S.S.; ANDRADE, E.C.; ZERBINI, F.M. Characterization of Tomato yellow spot virus, a novel tomato-infecting begomovirus in Brazil. Pesquisa Agropecuária Brasileira, v.42, p.1335-1343, 2007.

COHEN, S.; NITZANY, F.E. Transmission and host range of Tomato yellow leaf curl virus. Phytopathology, v.56, p.1127-1131, 1966.

COHEN, S.; DUFFUS, J.E.; LARSEN, R.C.; LIU, H.; FLOCK, R.A. Purification, serology and vector relationships of Squash leaf curl virus, a whitefly-transmitted geminivirus. Phytopathology, v.73, p.1669-1673, 1983.

COLARICCIO, A.; EIRAS, M.; CHAVES, A.L.R.; BERGMAN, J.C.; ZERBINI, F.M.; HARAKAVA, R.; CHAGAS, C.M. Tomato yellow vein streak virus, a new begomovirus on tomato from Brazil: complete DNA A sequence and some molecular and biological features. Journal of Plant Pathology, v.89, p.385390, 2007.

COSTA, A.S. Whitefly-transmitted plant diseases. Annual Review of Phytopathology, v.14, p.429-449, 1976.

DELLAPORTA, S.L.; WOOD, J.; HICKS, J.B. A plant DNA minipreparation: version II. Plant Molecular Biology Reporter, v.1, p.19-21, 1983.

FARIA, J.C.; SOUZA-DIAS, J.A.C.; SLACK, S.A.; MAXWELL, D.P. A new geminivirus associated with tomato in the State of São Paulo, Brazil. Plant Disease, v.81, p.423, 1997.

FERNANDES, F.R.; ALBUQUERQUE, L.C.; GIORDANO, L.B.; BOITEUX, L.S.; ÁVILA, A.C.; INOUE-NAGATA, A.K. Diversity and prevalence of Brazilian bipartite begomovirus species associated to tomatoes. Virus Genes, v.36, p.251$258,2008$.

FRANÇA, F.H.; VILLAS-BOAS, G.L.; CASTELO-BRANCO, M. Occurrence of Bemisia argentifolli Bellows \& Perring (Homoptera:Aleyrodidae) in the Federal District. Anais da Sociedade Entomológica do Brasil, v.25, p.369-372, 1996.

GHANIM, M; CZOSNEK, H. Tomato yellow leaf curl geminivirus (TYLCV-Is) is transmitted among whiteflies (Bemisia tabaci) in a sex-related manner. Journal of Virology, v.74, p.47384745, 2000.

GHANIM, M.; MORIN, S.; ZEIDAN, M.; CZOSNEK, H. Evidence for transovarial transmission of tomato yellow leaf curl virus by its vector, the whitefly Bemisia tabaci. Virology, v.240, p.295-303, 1998.

IDRIS, A.M.; BROWN, J.K. Sinaloa tomato leaf curl virus geminivirus: biological and molecular evidence for a new subgroup III virus. Phytopathology, v.88, p.648-657, 1998.

LOURENÇÃO, A.L.; NAGAI, H. Surtos populacionais de Bemisia tabaci no Estado de São Paulo. Bragantia, v.53, p.53-59, 1994.

MANSOUR, A.; AL-MUSA, A. Tomato yellow leaf curl virus: host range and virus vector relationship. Plant Pathology, v.41, p.122-125, 1992.

MASON, G.; CACIAGLI, P.; ACCOTTO, G.P.; NORIS, E. Realtime PCR for the quantitation of Tomato yellow leaf curl Sardinia virus in tomato plants and in Bemisia tabaci. Journal of Virological Methods, v.147, p.282-289, 2008.

MEHTA, P.; WYMAN, J.A.; NAKHLA, M.K.; MAXWELL, D.P. Transmission of Tomato yellow leaf curl geminivirus by Bemisia tabaci (Homoptera: Aleyrodidae). Journal of Economic Entomology, v.87, p.1291-1297, 1994a.
MEHTA, P.; WYMAN, J.A.; NAKHLA, M.K.; MAXWELL, D.P. Polymerase chain reaction detection of viruliferous Bemisia tabaci (Homoptera: Aleyrodidae) with two tomato-infecting geminiviruses. Journal of Economic Entomology, v. 87, p.1285-1290, $1994 b$.

MUNIYAPPA, V.; VENKATESH, H.M.; RAMAPPA, H.K.; KULKARNI, R.S.; ZEIDAN, M.; TARBA, C.Y.; GHANIM, M.; CZOSNEK, H. Tomato leaf curl virus from Bangalore (ToLCVBan4): sequence comparison with Indian ToLCV isolates, detection in plants and insects, and vector relationships. Archives of Virology, v.145, p.1583-1598, 2000.

NATESHAN, H.M.; MUNIYAPPA, V.; SWANSON, M.M.; HARRISON, B.D. Host range, vector and serological relationships of Cotton leaf curl virus from southern India. Annals of Applied Biology, v.128, p.233-244, 1996.

NOZAKI, D.N. Estudo biológico, moleculares e citológicos de begomovirus infectando pimentão (Capsicum annuum) no Estado de São Paulo. Botucatu: UNESP/FCA, 2006. 87p. Tese (Doutorado).

PICÓ, B.; DÍEZ, M.J.; NUEZ, F. Viral diseases causing the greatest economic losses to the tomato crop. II. Tomato yellow leaf curl virus - a review. Scientia Horticultureae, v.67, p.151196, 1996.

POLSTON, J.E.; AL-MUSA, A.; PERRING, T.M.; DODDS, J.A. Association of the nucleic acid of Squash leaf curl geminivirus with the whitefly Bemisia tabaci. Phytopathology, v.80, p.850856,1990

RIBEIRO, S.G.; AMBROZEVICIUS, L.P.; ÁVILA, A.C.; BEZERRA, I.C.; CALEGARIO, R.F.; FERNANDES J.J.; LIMA M.F.; MELLO, R.N.; ROCHA, H.; ZERBINI, F.M. Distribution and genetic diversity of tomato-infecting begomovirus in Brazil. Archives of Virology, v.148, p.281-295, 2003.

RIBEIRO, S.G.; INOUE-NAKATA, A.K.; DANIELS, J.; ÁVILA, A.C. Potato deforming mosaic disease is caused by an isolate of Tomato yellow vein streak virus. Plant Pathology, v.55, p.569, 2006.

ROJAS, M.R.; GILBERTSON, R.T.; RUSSEL, D.R.; MAXWELL, D.P. Use of degenerate primers in the polymerase chain reaction to detective whitefly-transmitted geminivirus. Plant Disease, v.77, p.340-347, 1993.

RUBINSTEIN, G.; CZOSNEK, H. Long-term association of Tomato yellow leaf curl virus with its whitefly vector Bemisia tabaci: effect on the insect transmission capacity, longevity and fecundity. Journal of General Virology, v.78, p.2683-2689, 1997.

SANTOS, C.D.G.; ÁVILA, A.C.; REZENDE, R.O. Estudo da interação de um begomovirus isolado de tomateiro com mosca branca. Fitopatologia Brasileira, v.28, p.664-673, 2003.

SOUZA-DIAS, J.A.C.; YUKI, V.A.; RIBEIRO, S.G.; RAVAGNANE, V.A. Risca amarela da nervura do tomateiro é causada por geminivirus que infecta batata. Summa Phytopathologica, v.22, p.57, 1996.

STONOR, J.; HART, P.; GUNTHER, M.; DE BARRO, P.; REZAIAN, M. A. Tomato leaf curl geminivirus in Australia: occurrence, detection, sequence diversity and host range. Plant Pathology, v.52, p.379-388, 2003.

VECCHIA, M.G.S.D., ROSA, D.D., BERGAMIN FILHO, A., AMORIM, L., REZENDE, J.A.M.; RIBEIRO, A. Dinâmica temporal e espacial da begomovirose causada por tomato yellow vein streak virus em tomateiro na região de Campinas - SP. Summa Phytopathologica, v.33, p.388-395, 2007.

ZEIDAN, M; CZOSNEK, H. Acquisition of Tomato yellow leaf curl virus by the whitefly Bemisia tabaci. Journal of General Virology, v.72, p.2607-2614, 1991 .

Received July 04, 2008

Accepted May 19, 2009 